\title{
Model Pembelajaran Explicit Instruction guna Meningkatkan Prestasi Belajar Matematika
}

\author{
I Wayan Sosiawan ${ }^{1}$ \\ 'SMP Negeri 2 Blahbatuh \\ Gianyar, Indonesia \\ email: sosiawannyoman@gmail.com
}

\begin{abstract}
Abstrak
Penelitian ini dilaksanakan di SMP di kelas VII F yang kemampuan siswanya untuk mata pelajaran Matematika masih sangat rendah. Tujuan penulisan penelitian tindakan kelas ini adalah untuk meningkatkan prestasi belajar Matematika siswa kelas VII F di SMP pada semester II tahun pelajaran 2018/2019 melalui penerapan model pembelajaran Explicit Instruction. Metode pengumpulan datanya adalah observasi dan tes prestasi belajar. Metode analisis datanya adalah deskriptif. Dengan hasil yang diperoleh dari penelitian ini adalah model pembelajaran yang diterapkan dapat meningkatkan prestasi belajar siswa. Ini terbukti dari hasil yang diperoleh pada awalnya hanya mencapai rata-rata 68,07 dan ketuntasan belajar $28,20 \%$, pada siklus I meningkat menjadi 73,84 dengan ketuntasan belajar $76,92 \%$ dan pada Siklus II meningkat menjadi 80,51 dengan ketuntasan belajar mencapai $94,87 \%$. Kesimpulan yang diperoleh dari penelitian ini adalah penerapan model pembelajaran Explicit Instruction dapat meningkatkan prestasi belajar Matematika siswa kelas VII F SMP pada semester II tahun pelajaran 2018/2019.
\end{abstract}

Kata Kunci: Model Pembelajaran Explicit Instruction, Prestasi Belajar.

\begin{abstract}
This research was conducted at SMP class VII F, where the students' ability for Mathematics was still very low. The purpose of this classroom action learning is to improve the mathematics learning achievement of class VII F students at SMP in the second semester of the 2018/2019 academic year through the application of the Explicit Instruction learning model. The data learning method is observation and learning achievement test. The data analysis method is descriptive. With the results obtained from this study is the learning model that is applied to improve student achievement. It is evident from the results obtained initially only reached an average of 68.07 and $28.20 \%$ completeness in learning, in the first cycle it increased to 73.84 with $76.92 \%$ completeness in learning and in the second cycle it increased to 80.51 with complete learning reached $94.87 \%$. The conclusion obtained from this research is that the application of the Explicit Instruction learning model can improve the mathematics learning achievement of class VII F students of SMP in the second semester of the 2018/2019 academic year.
\end{abstract}

Keywords: Explicit Instruction Learning Model, Learning Achievement.

\section{Pendahuluan}

Pendidikan adalah aspek penting bagi pengembangan sumber daya manusia. Pendidikan juga diyakini mampu menanamkan pengalaman bagi semua orang untuk mempelajari pengetahuan dan keterampilan sehingga dapat diperoleh manusia yang produktif. Salah satu hal yang paling mendasar dalam dunia pendidikan adalah bagaimana usaha untuk menginovasi proses pembelajaran sehingga memperoleh hasil yang maksimal.

Guru sebagai ujung tombak pendidikan dan keberhasilan pelaksanaan UU Sistem Pendidikan, diharapkan memiliki pengetahuan dan keterampilan yang berhubungan dengan tugas dan tanggung jawabnya selaku guru yang profesional. Guru yang profesional harus

\footnotetext{
${ }^{*}$ Corresponding author.

Received 03 Februari 2020; Accepted 31 July 2020; Available online 1 September 2020

(C) 2020 MPI. All Rights Reserved
} 
memiliki seperangkat kompetensi (pengetahuan, keterampilan dan perilaku) untuk mampu menjalankan tugas yang diembannya. Berdasarkan UU no. 14 Tahun 2005 tentang Guru dan Dosen pada Bab IV Pasal 10 ayat (1) menyatakan bahwa Kompetensi guru sebagaimana dimaksud dalam Pasal 8 meliputi kompetensi pedagogik, kompetensi kepribadian, kompetensi sosial, dan kompetensi profesional yang diperoleh melalui pendidikan profesi.

Sementara itu, Ali Idrus menyatakan untuk menghadapi tantangan zaman dengan kemajuan teknologi informasi dan ilmu pengetahuan yang serba cepat dibutuhkan guru profesional yang intelektual dan bermoral. Hal itu sesuai dengan pendapat Giroux (dalam Idrus, 2009: 157) yang disampaikannya bahwa sosok guru yang mampu memunculkan inovasi dalam pendidikan adalah guru yang menurutnya mau terus berkembang dan belajar seumur hidup, tidak pernah puas dengan apa yang dimengerti, mau membawa perubahan, berpikir kritis, rasional bebas mengembangkan pikiran, reflektif, berani membela kebenaran dan keadilan. Dan tidak dibutuhkan guru yang hanya mempertahankan status quo-nya dan menjalankan tugasnya seperti tukang.

Menyadari permasalahan yang sedang dihadapi, untuk mendukung semua yang telah dijelaskan di atas. Guru selaku peneliti yang bertugas di SMP Negeri 2 Blahbatuh mencoba melakukan koreksi dan refleksi atas prestasi belajar awal siswa kelas VII F semester II tahun pelajaran 2018/2019 yang ditemukan pada saat observasi. Rata-rata nilai mata pelajaran Matematika siswa yang diperoleh hanya mencapai 68,07 dengan prosentase ketuntasan belajar sebesar $28.20 \%$. Nilai tersebut ternyata masih jauh dari Kriteria Ketuntasan Minimal (KKM) yang ditetapkan sekolah yaitu 73,00.

Pengamatan dan perenungan kembali jalannya proses pembelajaran yang telah dilakukan membuahkan kesimpulan beberapa faktor yang penyebabnya adalah(a) kurang seriusnya guru dalam melakukan persiapan untuk memulai proses pembelajaran; (b) kurangnya daya dukung berupa media/sumber belajar yang dimanfaatkan guru saat pelaksanaan pembelajaran, dan (c) kurangnya daya kreativitas siswa akibat waktu belajar banyak dikuasai guru sehingga ketika usai proses pembelajaran pengetahuan dan pemahaman yang harusnya dikuasai siswa belum tecapai.

Mempertimbangkan kondisi tersebut, guru melakukan konsultasi dengan beberapa teman sejawat dan ditemukan solusi yang menurut pertimbangan guru akan mampu menuntaskan permasalahan yang sedang dihadapi. Solusi tersebut adalah mengupayakan model pembelajaran berbasis masalah untuk melatih siswa agar dapat berpikir kreatif dan kritis menghadapi masalah. Dukungan yang disiapkan guru untuk mewujudkan hal itu dengan mengupayakan dan memanfaatkan media pembelajaran yang mampu menarik minat dan konsentrasi mereka untuk belajar. Hal itu dilakukan mempertimbangkan apa yang disampaikan Darmawan (2009: 66) yang mengkaji tentang media, model pembelajaran, dan perilaku belajar peserta didik, dengan pernyataan bahwa peranan teknologi informasi dan komunikasi dalam mengemas informasi pembelajaran akan memperkuat stimulus dalam proses pembelajaran. Dengan stimulus ini pembelajar akan mampu mengoptimalkan perilaku belajarnya.

Dasar kajian inilah yang kemudian dijadikan landasan guru untuk melakukan pembuktian sendiri dalam proses pembelajaran yang dilakukan, sejauh mana model pembelajaran yang dilaksanakan secara kreatif dengan media pembelajaran yang bertumpu pada kemajuan teknologi informasi dapat meningkatkan prestasi belajar siswa

Adapun langkah yang diambil untuk memperbaiki prestasi belajar siswa yaitu dengan tindakan perbaikan yang selanjutnya disusun dalam bentuk penelitian tindakan kelas. Dengan cara ini diharapkan peserta didik akan tertarik untuk berinteraksi dalam pembelajaran sehingga akan meningkatkan kemampuan dan keterampilannya.

\section{Metode Penelitian}

Penelitian ini dilaksanakan di SMP Negeri 2 Blahbatuh. Jadwal pelaksanaaan penelitian ini adalah pada semester II tahun pelajaran 2018/2019 (antara bulan Januari s.d Juni 2019). Penelitian yang dilakukan termasuk penelitian tindakan. Oleh karenanya, rancangan yang khusus untuk sebuah penelitian tindakan sangat diperlukan. Peningkatan diri 
untuk hal yang lebih baik ini dilakukan terus menerus sampai tujuan tercapai (Arikunto et al., 2016: 6-7)

Untuk penelitian ini penulis memilih rancangan penelitian tindakan yang disampaikan oleh Arikunto (2010: 6) seperti terlihat pada gambar berikut.

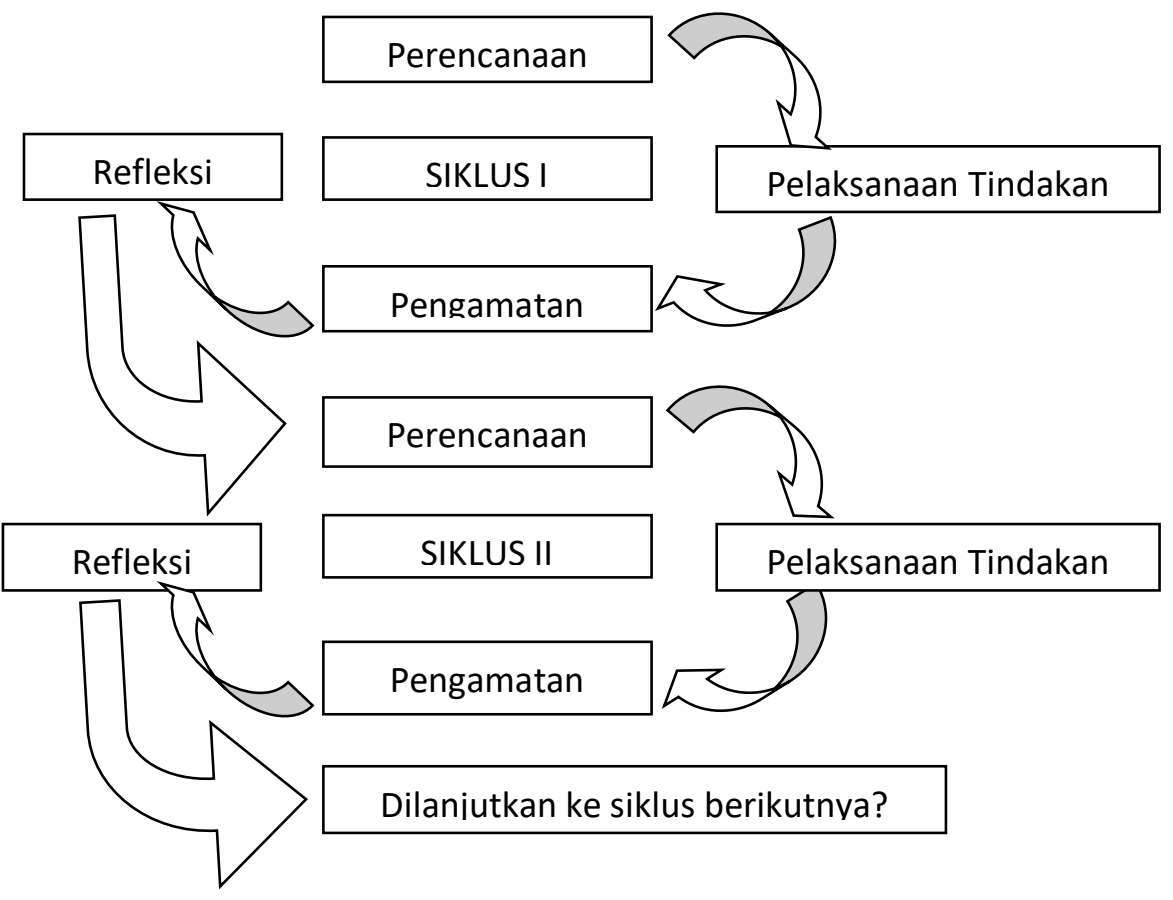

Gambar 1. Gambar Rancangan Penelitian Tindakan Kelas (Arikunto 2010: 6)

\section{Siklus I}

Berdasarkan bagan, tahapan kegiatan penelitian dapat dijelaskan sebagai berikut.

\section{Perencanaan Tindakan}

Adapun perencanaan yang dilakukan untuk melaksanankan penelitian tindakan kelas adalah sebagai berikut.

1) Berkoordinasi dengan kepala sekolah untuk melaksanakan penelitian

2) Melakukan refleksi awal dengan melihat prestasi belajar Matematika siswa sebelum dilaksanakan penelitian.

3) Melakukan analisis kurikulum untuk mengetahui standar kompetensi, kompetensi dasar dan menyusun silabus yang disampaikan kepada siswa dengan menggunakan model pembelajaran Explicit Instruction.

4) Menyusun Rencana Pelaksanaan Pembelajaran (RPP) dilengkapi LKS yang dirancang. Langkah-langkah pembelajarannya diarahkan pada model pembelajaran Explicit Instruction untuk materi yang diajarkan.

5) Menyusun lembar penilaian dan tes/evaluasi berupa tes prestasi belajar dan kuesioner motivasi belajar.

6) Membuat ringkasan materi yang dibahas.

7) Membuat instrumen untuk penelitian tindakan kelas berupa lembar refleksi.

\section{Pelaksanaan Tindakan}

Dalam pelaksanaan ini disusun sesuai dengan tahap pelaksanaan penerapan model pembelajaran Explicit Instruction dalam mata pelajaran Matematika untuk mengetahui prestasi belajar siswa. Pada setiap siklus penelitian terdiri dari 4 kali pertemuan. 3 kali pertemuan untuk melaksanakan proses pembelajaran dan 1 kali pertemuan untuk melaksanakan evaluasi atau tes prestasi belajar dan mengukur motivasi belajar siswa. Langkah-langkahnya adalah sebagai berikut. 
1) Persiapan pada awal pembelajaran

Pada tahap ini, kegiatan yang dilaksanakan adalah mempersiapkan perangkat pembelajaran, membentuk kelompok learning komunity, menetukan skor awal, mengatur tempat duduk dan melakukan kegiatan apersepsi.

2) Pelaksanaan pembelajaran

Langkah-langkah dalam pelaksanaan tindakan ini adalah dilaksanakan sesuai dengan Rencana Pelaksanaan Pembelajaran (RPP) yang telah disusun dan disiapkan dengan menerapkan tahap-tahap model pembelajaran Explicit Instruction.

3. Observasi / Evaluasi

Pada pertemuan ke 4, guru melaksanakan tes prestasi belajar dan mengukur motivasi belajar siswa. Kegiatan yang dilakukan pada tahap evaluasi yaitu memberikan lembar tes evaluasi kepada siswa yang bertujuan untuk mengetahui prestasi belajar siswa dan kuesioner motivasi belajar untuk mengetahui tingkat motivasi belajar siswa setelah dilaksanakannya pembelajaran dengan model pembelajaran Explicit Instruction. Hasil evaluasi akan menjadi acuan bagi peneliti dalam merancang pembelajaran pada siklus berikutnya (siklus II).

4. Refleksi

Refleksi ini dilakukan untuk melihat dan mengkaji hasil tindakan pada siklus I mengenai prestasi belajar Matematika dan motivasi belajar siswa. Hasil kajian tindakan siklus I ini, selanjutnya dipikirkan untuk dicari dan ditetapkan beberapa alternatif tindakan baru yang diduga lebih efektif untuk meningkatkan prestasi belajar Matematika. Alternatif tindakan ini ditetapkan menjadi tindakan baru pada rencana tidakan dalam penelitian.

Metode yang digunakan untuk menganalisis data hasil penelitian ini adalah metode deskriptif. Untuk data kuantitatif dianalisis dengan mencari mean, median, modus, membuat interval kelas dan melakukan penyajian dalam bentuk tabel dan grafik.

1. Rata-rata (mean) dihitung dengan: Jumlah nilai Jumlah siswa

2. Median (titik tengahnya) dicari dengan mengurut data/nilai siswa dari yang terkecil sampai terbesar. Setelah diurut apabila jumlah data ganjil maka mediannya adalah data yang di tengah. Kalau jumlahnya genap maka dua data yang di tengah dijumlahkan dibagi 2 (dua).

3. Modus (angka yang paling banyak/paling sering muncul) setelah diasccending/diurut angka tersebut

4. Untuk persiapan penyajian dalam bentuk grafik maka hal-hal berikut dihitung terlebih dahulu.

1. Banyak kelas $(K)=1+3,3 \times \log (N)$

2. Rentang kelas $(r)=$ skor maksimum - skor minimum

3. Panjang kelas interval (i) $=\frac{r}{K}$

Indikator keberhasilan penelitian yang diusulkan dalam penelitian ini pada siklus I dan siklus II mencapai nilai rata-rata minimal 74,00 dengan ketuntasan belajar minimal $85 \%$.

\section{Hasil Dan Pembahasan}

Hasil yang diperoleh dari kegiatan awal menunjukan perolehan nilai rata rata kelas prestasi belajar Matematika masih sangat rendah, yaitu dengan perolehan skor nilai secara klasikal yaitu 2655 dan rata rata hanya mencapai 68,07, dimana siswa yang mencapai persentase ketuntasan belajar $28,20 \%$, dan yang tidak mencapai ketuntasan adalah $71,79 \%$, dengan tuntutan KKM untuk mata pelajaran Matematika di kelas VII F SMP Negeri 2 Blahbatuh adalah dengan nilai 73,00.

Pada siklus I sudah diupayakan untuk perbaikan pembelajaran untuk meningkatkan prestasi belajar Matematika dengan menggunakan model pembelajaran Explicit Instruction. 
Peneliti telah giat melakukan kegiatan yang susuai dengan kebenaran teori yang ada sehingga peneliti memperoleh hasil yang lebih baik dari proses awal, yaitu dengan rata rata nilai 73,84 dari jumlah nilai 2880 seluruh siswa di kelas VII F SMP Negeri 2 Blahbatuh, dan prosentase ketuntasan belajarnya adalah $76,92 \%$, yang tidak tuntas adalah $23,07 \%$. Hasil ini belum maksimal, karena belum mecapai indikator keberhasilan penelitian yang mencanangkan dengan minimal prosentase ketuntasan belajar $85,00 \%$.

Dengan tindakan yang sangat maksimal dan pelaksanaan yang betul-betul mengikuti kebenaran teori sesuai dengan model pembelajaran Explicit Instruction dalam pembelajaran Matematika di kelas VII F SMP Negeri 2 Blahbatuh, dimana hasil yang diperoleh pada siklus II ini ternyata prestasi belajar Matematika meningkat secara signifikan dengan nilai rata-rata 80,51 , dan ketuntasan belajarnya adalah $100 \%$.

Hasil yang diperoleh dari awal, siklus I dan siklus II digambarkan dalam bentuk tabel dan grafik seperti berikut:

Tabel 01. Data Prestasi Belajar Siswa Kelas VII F SMP Negeri 2 Blahbatuh

\begin{tabular}{cccc}
\hline DATA & AWAL & SIKLUS I & SIKLUS II \\
\hline Rata Rata Kelas & 68,07 & 73,84 & 80,54 \\
Persentase Ketuntasan & $28,20 \%$ & $76,92 \%$ & $94,87 \%$ \\
\hline
\end{tabular}

Hasil penelitian ini sejalan dengan hasil penelitian yang dilakukan oleh Utari, dkk (2016) dengan judul Pengaruhmodel Pembelajaran Explicit Instruction Berbantuan Lingkungan Alam Sekitar Terhadap Hasilbelajar IPA Siswa Kelas IV. Berdasarkan hasil analisis data, diperoleh thitung $=3,712$ dan ttabel (pada taraf signifikansi $5 \%$ ) $=1,684$. Hal ini berarti bahwa thitung $>$ ttabel.Dari rata-rata hitung, diketahui rata-rata kelompok eksperimen $=20,28$ dilihat dari hasil konversi tergolong kriteria sangat baik dan rata-rata kelompok kontrol $=16$ tergolong kriteria baik. Hal ini berarti penerapan model pembelajaran Explicit Instruction berbantuan lingkungan alam sekitar berpengaruh positif terhadap hasil belajar IPA siswa kelas IV di MIN Air Kuningtahun pelajaran 2015/2016.

Selanjutnya penelitian yang dilakukan oleh Silma (2017) dengan judul Pengaruh Penerapan model Pembelajaran Explicit Instruction Terhadap Motivasi Dan Hasil Belajar Siswa Kelas XI IPS Pada Pelajaran Ekonomi (Akuntansi) di SMAN 1 Langgam Kabupaten Pelalawan. Berdasarkan hasil penelitian dan pembahasan maka dapat disimpulkan bahwa: 1) Perhitungan dengan menggunakan uji $t$, diperoleh thitungsebesar 8,37sedangkan t tabel 2,04 pada taraf signifikan 0,05, karena thitung lebih besar dari $t$ tabel. Dengan demikian dapat disimpulkan bahwa terjadi peningkatan motivasi belajar siswa setelah menggunakan model pembelajaran Explicit instruction dari pada masih menggunakan model pembelajaran konvensional. 2) Rata-rata hasil belajar siswa mengalami peningkatan, pada skor dasar jumlahyang tidak tuntas 15 siswa, pada ulangan harian 1 yang tidak tuntas 9 siswa dan ulangan harian II yang tidak tuntas 4 orang siswa. Ini membuktikan bahwa setelah diterapkannya model pembelajaran Explicit Instruction terjadi penurunan siswa yang tidak tuntas.

\section{Simpulan}

Temuan dalam penelitian ini dari data awal ada 28 siswa mendapat nilai dibawah KKM dan pada siklus I menurun menjadi 11 siswa dan siklus II hanya 2 siswa mendapat nilai di bawah KKM. Nilai rata-rata awal 68,07 naik menjadi 73,84 pada siklus I dan pada siklus II naik menjadi 80,51 . Dari data awal siswa yang tuntas hanya 11 orang sedangkan pada siklus I menjadi lebih banyak yaitu 30 siswa dan pada siklus II sebanyak 37 siswa. Berdasarkan temuan di atas, dapat disimpulkan bahwa: penerapan model pembelajaran Explicit Instruction secara efektif dapat meningkatkan prestasi belajar Matematika siswa kelas VII F semester II SMP Negeri 2 Blahbatuh tahun pelajaran 2018/2019. 


\section{Daftar Pustaka}

Arikunto Suharsimi, Suhardjono, Supardi.2006. Penelitian Tindakan. Kelas. Jakarta: Bumi Aksara.

Arikunto, S. 2010. Prosedur Penelitian Suatu Pendekatan Praktik. Jakarta: Rineka Cipta.

Asikin dan Pujiadi. Lembaran IImu Kependidikan Jilid 37, NO. 1, Juni 2008. Pengaruh Model Pembelajaran Matematika Creative Problem Solving (CPS) Berbantuan CD Interaktif Terhadap Kemampuan Pemecahan Masalah Pada Siswa Kelas X SMA Negeri 1 Semarang. FMIPA Unnes.

Idrus, M. 2009. Metode penelitian IImu Sosial. Yogyakarta: PT. Gelora Akasara.

Rahman, B. 2009.Skripsi.Perbandingan Kemampuan Koneksi Matematik Siswa yang Pembelajarannya Menggunakan Model Creative Problem Solving (CPS) dengan Siswa yang Pembelajarannya Menggunakan Model Konvensional. FPMIPA UPI. Bandung.

Silma, Elghina. 2017. Pengaruh Penerapan model Pembelajaran Explicit Instruction Terhadap Motivasi Dan Hasil Belajar Siswa Kelas XI IPS Pada Pelajaran Ekonomi (Akuntansi) di SMAN 1 Langgam Kabupaten Pelalawan. Pekbis Jurnal, Vol.9, No.1, Maret2017:68-76.

Utari, Rahmawati, dkk. 2016. Pengaruhmodel Pembelajaran Explicit Instruction Berbantuan Lingkungan Alam Sekitar Terhadap Hasilbelajar IPA Siswa Kelas IV. e-Journal PGSD Universitas Pendidikan GaneshaJurusan PGSD Vol: 4 No: 1. 